Doi: $10.4274 /$ vhd.0001

Viral Hepatitis Journal 2017;23(3):65-70

\title{
Percutaneous Liver Needle Biopsy Methods Can Be Safe and Effective in Patients with Viral Hepatitis
}

\author{
Viral Hepatit Hastalarında Perkutan Karaciğer lğne Biyopsi Yöntemleri Güvenli ve Etkindir
}

\author{
Zehra KARACAER1 , Fatma YILMAZ KARADAĞ², Gül DURMUŞ3, Hüseyin ÇIÇEK4, Emine PARLAK5, \\ Alpay AR|6, Selma TOSUN6, Yavuz DURMUȘ7, Suat EREN8, Zehra ADIBELL19

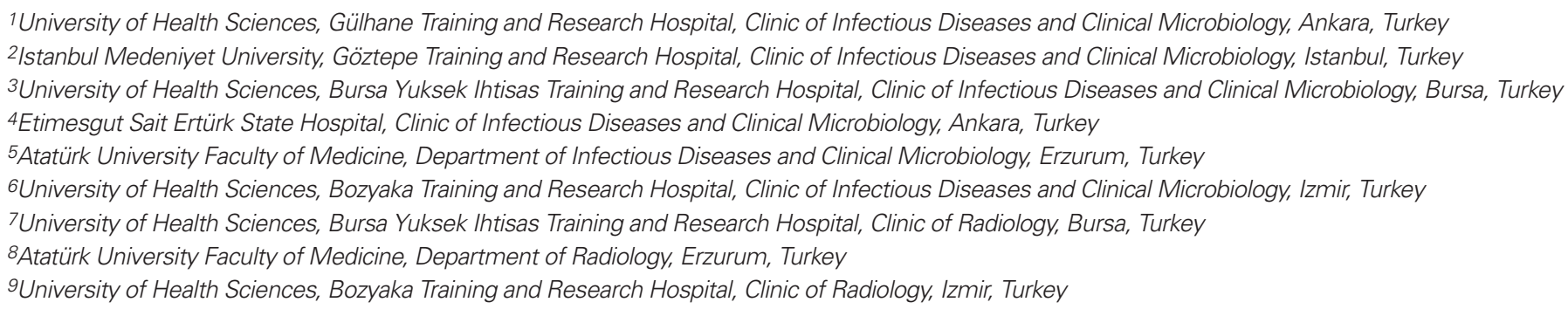

\section{ABSTRACT}

Objectives: The aims of this study were to evaluate the biopsy methods used in terms of safety, and effectiveness as well as incidence, and severity of complications.

Materials and Methods: This study was conducted as a prospective, observational study with the participation of five centers in Turkey. Any patient complaints and/or complications were also recorded. The patients' pain severity was determined by an established scoring method.

Results: This research included 221 chronic hepatitis patients and 12 physicians. With regard to the biopsies, $71.9 \%$ were ultrasoundguided and $28.1 \%$ were blind biopsies. $71 \%$ of patients had complaints (mostly pain) and $19.9 \%$ developed complications; however, no mortality occurred. It was observed that patient's complaints were significantly correlated with the physician's age, level of biopsy experience, and number of biopsies performed yearly. It was determined that the biopsy method was not affective factor in terms of the development of severe pain after biopsy. The use of a $16 \mathrm{G}$ biopsy needle was found to increase the probability of severe pain occurrence by about eight times.

Conclusion: Severe pain was not affected by the biopsy method or patient-specific factors, and was a result of the size of the biopsy needle used and the characteristics of the practitioner.

Keywords: Liver, viral hepatitis, biopsy, complication
$0 ̈ Z$

Amaç: Bu çalışmada karaciğer biyopsi yöntemlerinin güvenilirliği, etkinliği ve komplikasyonların şiddetinin değerlendirilmesi amaçlanmıştır.

Gereç ve Yöntemler: Bu araştırma Türkiye'de beş merkezin katılımıyla prospektif ve gözlemsel olarak gerçekleştirilmiştir. Hastaların şikayetleri ve/veya komplikasyonlar kaydedilmiştir. Hastaların ağrı şiddeti puanlama yöntemi ile belirlenmiştir.

Bulgular: Çalışmaya 221 kronik viral hepatit hastası ve 12 hekim katılmıştır. Biyopsilerin \%71,9'u ultrasonografi eşliğinde, \%28,1 kör biyopsi yöntemi ile yapılmıştır. Hastaların \%71'inde şikayet (çoğunluğu ağrı) ve \%19,9'unda komplikasyon gelişmiştir. Ancak mortalite gözlenmemiştir. Biyopsiyi yapan hekimin yaş grubu, biyopsi deneyim süresi ve yıllık biyopsi sayısı ile şikayetlerin oluşması arasında anlamlı ilişki saptanmıştır. Biyopsi sonrası şiddetli ağrı gelişimi açısından biyopsi yönteminin etkili bir faktör olmadığı belirlenmiştir. Şiddetli ağrı varlığını 16G biyopsi iğnesi kullanmanın yaklaşık sekiz kat arttırdığı saptanmıştır.

Sonuç: Şiddetli ağrının biyopsi yöntemi veya hastaya özgü faktörlerden etkilenmemekte, kullanılan biyopsi iğnesi ve uygulayııının özelliklerinden kaynaklanmaktadır.

Anahtar Kelimeler: Karaciğer, viral hepatit, biyopsi, komplikasyon

Karacaer Z, Yılmaz Karadağ F, Durmuş G, Çiçek H, Parlak E, Arı A, Tosun S, Durmuş Y, Eren S, Adıbelli Z. Percutaneous Liver Needle Biopsy Methods Can Be Safe and Effective in Patients with Viral Hepatitis. Viral Hepat J. 2017;23:64-70.

This study was presented as a poster presentation in XVIII. Turkish Infectious Diseases and Clinical Microbiology Congress, Antalya, 2017

Address for Correspondence: Zehra Karacaer MD, University of Health Sciences, Gülhane Training and Research Hospital, Clinic of Infectious Diseases and Clinical Microbiology, Ankara, Turkey Phone: +90312304 2000 E-mail: zehrakaracaer@yahoo.com ORCID ID: orcid.org/0000-0002-2658-4679 Received: 23.11.2017 Accepted: 19.12.2017

${ }^{(0)}$ Copyright 2017 by Viral Hepatitis Society / Viral Hepatitis Journal published by Galenos Publishing House. 


\section{Introduction}

Liver biopsies are necessary in the diagnosis of parenchymal liver diseases, monitoring disease progression, and/or treatment decisions. Although several noninvasive methods have been introduced recently, a liver biopsy still provides the best results. Tissue samples required for histopathological investigations can be obtained by either imaging-guided or blind biopsy methods. The blind biopsy methods include percutaneous needle, transvenous (transjugular), laparoscopic or open wedge (surgical) biopsies. Imaging-guided biopsy is performed in order to provide visual control in the diagnosis of a focal lesion in the liver. For this method, ultrasonography (USG) is usually preferred, while computed tomography is rarely utilized (1).

Biopsy is contraindicated in patients with a history of extrahepatic biliary obstruction, bacterial cholangitis, coagulation disorders, ascites, cystic lesions, and amyloidosis, as well as in uncooperative patients (2). In order to perform a liver biopsy, the platelet count should be higher than $60.000 / \mu \mathrm{L}$, the prothrombin time (PT) should be shorter than 4 seconds, the international normalized ratio (INR) value should be lower than 1.4, and the activated partial thromboplastin time (APTT) should not exceed 1.5 times the reference value. Therefore, performing a full blood count and coagulation analysis, and ruling out focal lesions within the liver with imaging methods are recommended before performing a biopsy (1).

Despite taking precautionary measures, the rates of biopsyrelated morbidity and mortality range from 0.08 to $0.34 \%$ and from 0 to $0.19 \%$, respectively (3). Cooperation status of the patient, advanced age, bleeding disorders, presence of underlying diseases (such as cirrhosis, ascites, or malignancy), biopsy experience of the person performing the biopsy, biopsy method used, diameter of the biopsy needle, and type and number of interventions are the factors most affecting the development of complications (4). The most common complication observed following a liver biopsy is mild pain felt in the biopsy area and the right shoulder. Severe pain in the abdomen may be indicative of serious complications, such as intra-abdominal hemorrhage or peritonitis (3). In addition, the following conditions may develop: major or minor bleeding, pneumothorax, hemothorax, organ perforation, bile peritonitis, infection, hemobilia, intrahepatic arteriovenous fistula, or neuralgia. In general, major complications requiring hospitalization occur within the first three hours after biopsy (4).

The objectives of this multicenter study were to determine the risk factors related to liver biopsy with prospective observations, and to evaluate two different biopsy methods (USG-guided and blind) in terms of safety and effectiveness as well as incidence and severity of complications.

\section{Materials and Methods}

\section{Study Design and Features of the Study Group}

This was a prospective, observational study conducted between July 1, 2015 and September 1, 2016, with the participation of five centers in Turkey. It consisted of patients, who presented to the infectious diseases and clinical microbiology clinics due to viral hepatitis and were scheduled for liver biopsy. Needle biopsies were performed by physicians in attendance at the infectious diseases and clinical microbiology and radiology clinics.
The patients' demographics, medical history, liver disease information, biopsy method, the type of needle used, complaints, complications, treatment administered after the biopsy, histopathological outcomes, characteristics of the pain felt, and follow-up information were recorded. Demographic characteristics and information about the liver biopsy experience of the physicians who performed the liver biopsies were also included in the data set.

\section{Liver Biopsy}

Each patient underwent a complete blood count and coagulation test to rule out any contraindication before the liver needle biopsy. Any medications or drugs that can cause coagulation disorders were discontinued before the biopsy. In patients with existing coagulation disorders, the liver biopsy was planned after they underwent proper treatment. Either a USG-guided or blind biopsy was performed under local anesthesia with a 14-18 gauge (G) needle. The liver parenchyma was assessed using the modified Knodell scoring system (Ishak) in the pathology laboratory of the relevant center. Patients with a histology activity index (HAl) between 0 and 7 were defined as mild, with the others having severe activity; those with a fibrosis score from 0 to 2 were considered to have mild fibrosis, with the others defined as severe.

\section{Biopsy Complications}

The patient's complaints were registered, and the clinical symptoms, blood pressure, and pulse were recorded in the clinic after the biopsy, with a full blood count ordered after two hours. Following the liver biopsy, any mild-to-severe pain, major or minor bleeding, pneumothorax, hemothorax, organ perforation, bile peritonitis, infection, hemobilia, and/or intrahepatic arteriovenous fistula development were defined as complication (4). A $4 \%$ reduction in the hematocrit control was defined as bleeding; this was considered to be minor if intervention was not necessary, and major if treatment was needed. For the blood pressure, a level lower than $90 / 60 \mathrm{mmHg}$, or a $20 \mathrm{mmHg}$ or higher drop in the systolic blood pressure and a $15 \mathrm{mmHg}$ or higher drop in diastolic blood pressure (compared with the pre-biopsy levels) were diagnosed as hypotension (5).

To determine pain severity, the patients were asked to report their pain numerically: no pain $=0$, intolerable pain $=10$, and the other pain severities were rated between 1 and 9 points (6). Any pain reported as six or higher was defined as "severe pain." Both the type of pain and the location were recorded at the $2^{\text {nd }}$ and $24^{\text {th }}$ hours after the liver biopsy, and at the time of presentation for the first follow-up examination.

\section{Inclusion and Exclusion Criteria}

Those patients and physicians who provided written consent were included in this research. In addition, pre-cirrhotic/cirrhotic patients using antiviral therapy (continued/stopped) were included in the study. However, patients who refused to participate, those under 18 years of age, and those in whom post-biopsy follow-ups could not be performed, as well as physicians who did not provide consent were excluded from the study.

\section{Ethical Issues}

The Declaration of Helsinki and Good Clinical Practice Guidelines were respected during the entire process of enrolling the patients in 
the study and collecting/analyzing/reporting the data. This research was approved by the Istanbul Medeniyet University, Göztepe Training and Research Hospital Ethics Committee (01.07.20152015/0090).

\section{Statistical Analysis}

The study data was transferred to the SPSS IBM 22.0 statistical program (SPSS Inc., Chicago, IL, USA) in order to perform the data control and analysis. The distribution of the data was evaluated using the Kolmogorov-Smirnov test. The descriptive data was shown as the frequency distribution and percentage, while the nonnormally distributed data was expressed as the median (minimummaximum).

The patients were grouped according to the biopsy methods, needle diameters, physicians' age groups, physicians' biopsy experience, and the physicians' academic degree and number of biopsy per year. The complaints, complications, and features of the liver materials were also analyzed. The categorical variables were compared using Pearson's chi-squared and Fisher's exact tests. The continuous variables were assessed using the Mann-Whitney $U$ and Kruskal-Wallis tests. A binary logistic regression analysis was used in the multiple analyses and a p value of less than 0.05 was considered statistically significant.

\section{Results}

\section{Patient Characteristics}

This research included 221 chronic viral hepatitis patients, with an $86.4 \%$ naivety rate. Of these patients, $67 \%$ were males and the median age was 36 (18-83) years. Liver biopsy was performed in 93.7\% of patients due to e hepatitis B virus (HBV) infection, $5.4 \%$ due to hepatitis $\mathrm{C}$ virus $(\mathrm{HCV}$ ) infection, and $0.9 \%$ due to $\mathrm{HBV}-\mathrm{HCV}$ coinfection. The median duration of the patients' knowledge of their chronic viral hepatitis was $6(1-37)$ years.

It was determined that $20.4 \%$ of patients had another chronic disease; $75.5 \%$ of patients with other chronic diseases used various drugs for these diseases and 3 patients used anticoagulant drugs. Of the patients included in this study, $26.7 \%$ had previously undergone liver biopsy and $22 \%$ had developed complications; the most common complication was severe pain (92.3\%). No coagulation disorders were observed in any of the patients.

\section{Characteristics of the Physicians Who Performed the Biopsies}

Out of the 12 physicians who participated, $81.9 \%$ were males, and the median age was $46(26-52)$ years. The median service duration in the field of specialization of the physicians was 5 (3-26) years, the median liver biopsy experience was $4(<0-23)$ years, and the median number of liver biopsy per year was 75 (20-240). Of the physicians, $71.9 \%$ were radiologists and $28.1 \%$ were infectious diseases specialists. Moreover, $48.4 \%$ of the biopsies were performed by specialists, $33 \%$ by assistants/research assistants, and $18.6 \%$ by chief assistants/academicians.

There was a significant difference when the physicians' yearly biopsy numbers and level of biopsy experience were compared according to their titles $(p<0.001)$. It was determined that those physicians who performed biopsies most frequently in one year were assistants/research assistants, and those with an experience of 6 years or longer were specialists. Although the number of biopsy per year was higher than 50 for all the assistants/research assistants, their experience was determined to be less than one year.

\section{Liver Needle Biopsy Outcomes and Related Factors}

With regard to liver biopsies, $71.9 \%$ were USG-guided and $28.1 \%$ were blind biopsies. The USG-guided biopsies were performed for the following reasons: $62.3 \%$ because of the clinical protocol, $32.1 \%$ because it was thought to be safer, $3.8 \%$ due to obesity, $1.3 \%$ due to narrowing in the intercostal space, and $0.6 \%$ due to old age. $16 \mathrm{G}$ biopsy needles were used in $67.9 \%$ of the cases, $18 \mathrm{G}$ in $23.5 \%, 14 \mathrm{G}$ in $5.9 \%$, and $17 \mathrm{G}$ in $2.7 \%$. Tru-Cut needles (67.9\%) and automatic biopsy needles (32.1\%) were used in USG-guided biopsies, and Menghini needles were used in blind biopsies.

In the histopathological outcomes, the median $\mathrm{HAl}$ value was $6(0-17)$ and the median fibrosis value was $1(0-5)$. Mild histological activity (75.6\%) and fibrosis $(75.1 \%)$ were detected in the majority of patients; however, no cirrhotic patients were seen in this study. Insufficient material was obtained from 11 patients; nine with USG-guided and two with blind biopsies. No significant correlation was found between obtaining insufficient material and the biopsy method or needle diameter $(p=0.524$ and $p=0.271$, respectively). A similar situation was observed in the characteristics of the biopsy physician, and no significant correlation was found between obtaining insufficient material and the age group, level of biopsy experience, or title of the physician $(p=0.368, p=1.00$, and $p=0.503$, respectively). There was a positive correlation between the length of the liver material and the number of portal areas $(r=0.281, p<0.001)$.

\section{Post-biopsy Complaints, Complications, and Related Factors}

Following the liver biopsy, the median duration to the follow-up on the first day was $6(3-48)$ hours. The median duration to the next follow-up day after the biopsy was 21 (5-90) days. Of the patients, $71 \%$ reported complaints: $76.5 \%$ had headache, $6.8 \%$ had shortness of breath, 3.2\% felt dizziness, $2.3 \%$ had nausea, $1.8 \%$ felt fatigue, $0.5 \%$ had palpitations, and $2.3 \%$ reported other complaints.

After the liver biopsy, $19.9 \%$ of patients developed complications, including severe pain (97.7\%) and hypotension (2.3\%). The pain was felt in the liver region in $60.6 \%$, in the right shoulder in $25.8 \%$, around the abdomen in $4.5 \%$, and in other regions (headache in 1 patient, lower back pain in 1 patient) in $0.9 \%$ of the patients. In addition, $12.2 \%$ reported that they received nonnarcotic analgesics because of pain.

The most common complaints of any type following the biopsy occurred inpatients $\leq 30$ years old $(p=0.001)$. However, no significant correlation was found between the complaints and the patients' gender, HAl, fibrosis level, type of hepatitis, or presence of another chronic disease $(p=0.5, p=0.826, p=0.292, p=0.222$, and $\mathrm{p}=0.056$, respectively). The complaints were experienced more commonly after the blind biopsy procedure, and with the use of a $16 \mathrm{G}$ needle $(p<0.001$ and $p=0.007$, respectively) (Table 1$)$. There 
was a significant correlation between the occurrence of complaints and the physician's age group, level of biopsy experience, and the number of biopsy/year $(p=0.046, p<0.001$, and $p<0.001$, respectively) (Table 2 ).

It was found that the biopsy management, patient's age and gender, HAl and fibrosis levels, type of hepatitis, and presence of another chronic disease were not affective in terms of the development of severe disease after biopsy $(p=0.464, p=0.328$, $p=0.516, p=0.845, p=0.783, p=0.162$, and $p=0.274$, respectively). In addition, no significant correlation was observed between the development of severe pain and diameter of the needle used ( $p=0.322$ ). In USG-guided biopsies, severe pain developed after biopsy in $27.6 \%$ of patients in whom $16 \mathrm{G}$ needles were used $(p=0.001)$. Regardless of the method, severe pain was observed most frequently after the use of a $16 \mathrm{G}$ needle $(p=0.001)$ (Table 1). In addition, it was observed that age and title of the physician who performed the biopsy affected the development of severe pain (Table 2).

The results of the multiple regression analysis did not reveal any risk factor that would affect the presence of a complaint. However, the use of a $16 \mathrm{G}$ biopsy needle was found to increase the presence of severe pain by about eight times $[B=2.1, p=0.007$, Exp. $(B)=8.167]$.

\section{Discussion}

In this study, life-threatening complications did not develop after liver biopsy. However, severe pain and hypotension were observed in $19.9 \%$ of patients. This rate is higher than in other studies $(7,8)$. Since this study was a prospective and observational study, we think that we follow patients more closely and question the existence of pain more rigorously. Therefore, complications may be more frequently observed.

Mortality after liver biopsy is very rare $(7,8,9,10)$. After biopsy, pain and bleeding are the most common complications $(7,8,9)$. A population-based study in Canada reported that 4275 percutaneous liver biopsies were performed on 3627 patients over nine years and only $32(0.75 \%)$ patients developed significant complications. It was also reported that mortality developed in six patients $(0.14 \%)$ and the most frequent complications were pain and bleeding requiring hospitalization. The cause of mortality was massive bleeding in five patients and aspiration pneumonia and congestive heart failure in the other patient (11).

Pain is the most common complication after liver biopsies $(7,8,9)$. Similarly, in this study, the most common complication was severe pain. The mechanism of post-biopsy pain is often not clearly explained. Most likely, however, pain occurs after bile leakage from the biopsy line or capsular swelling after bleeding. There may also be pain transmitted from the skin or the liver capsule or both. Generally, pain begins as viscerosomatic pain in the right shoulder, peaks and disappears with pain in the biopsy area $(3,4)$. The frequency and severity of pain decreases deliberately within 24 hours of maximum level in the first 30 minutes (12). In this study, the pain observed in the biopsy area was lasting on average two days.

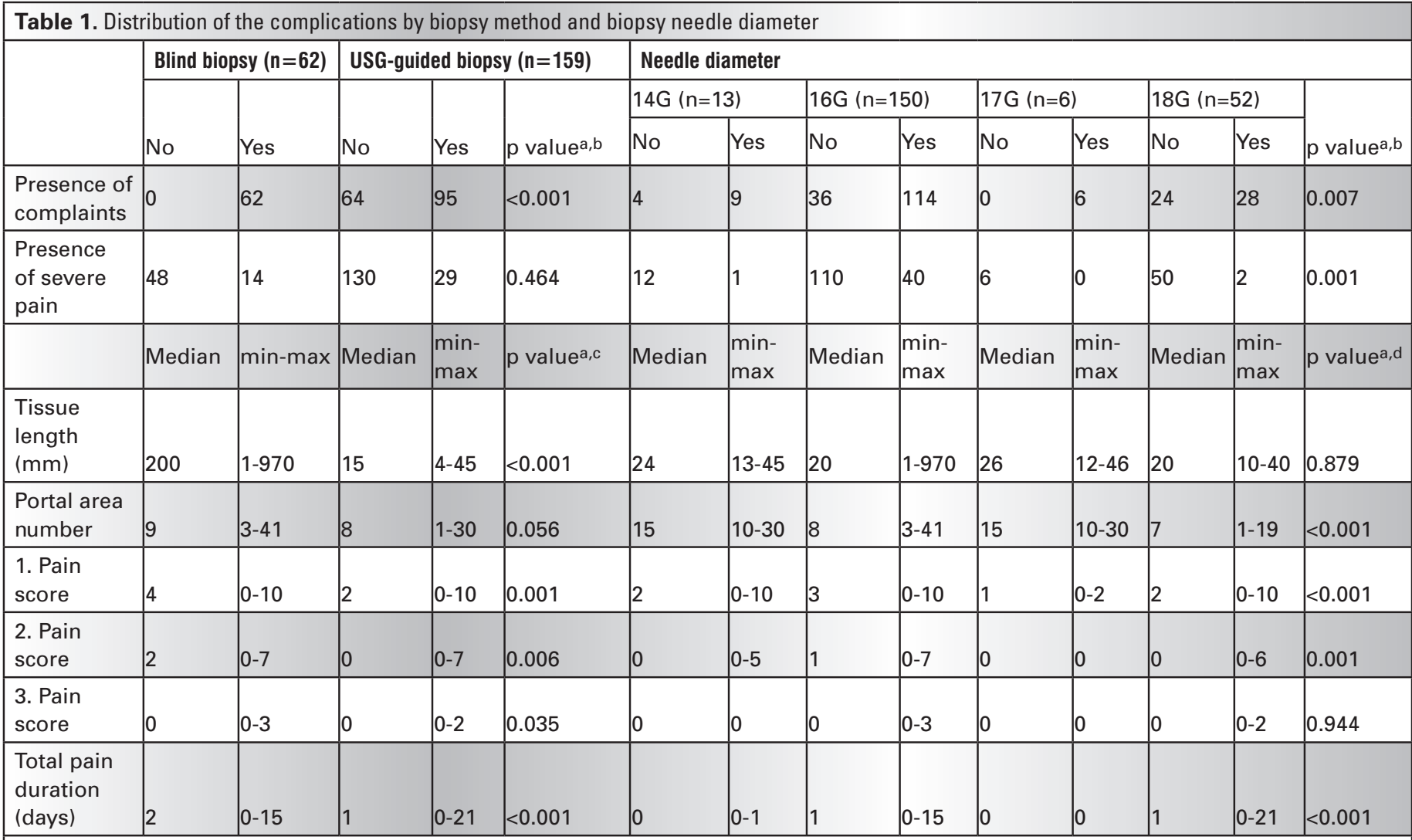

USG: Ultrasonography, 1. pain score: $2^{\text {nd }}$ hour after biopsy, 2. pain score: $24^{\text {th }}$ hour after biopsy, 3. pain score: First day of follow-up after biopsy, G: Gauge, min: minimum,

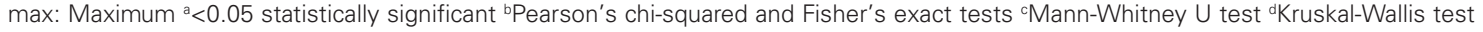




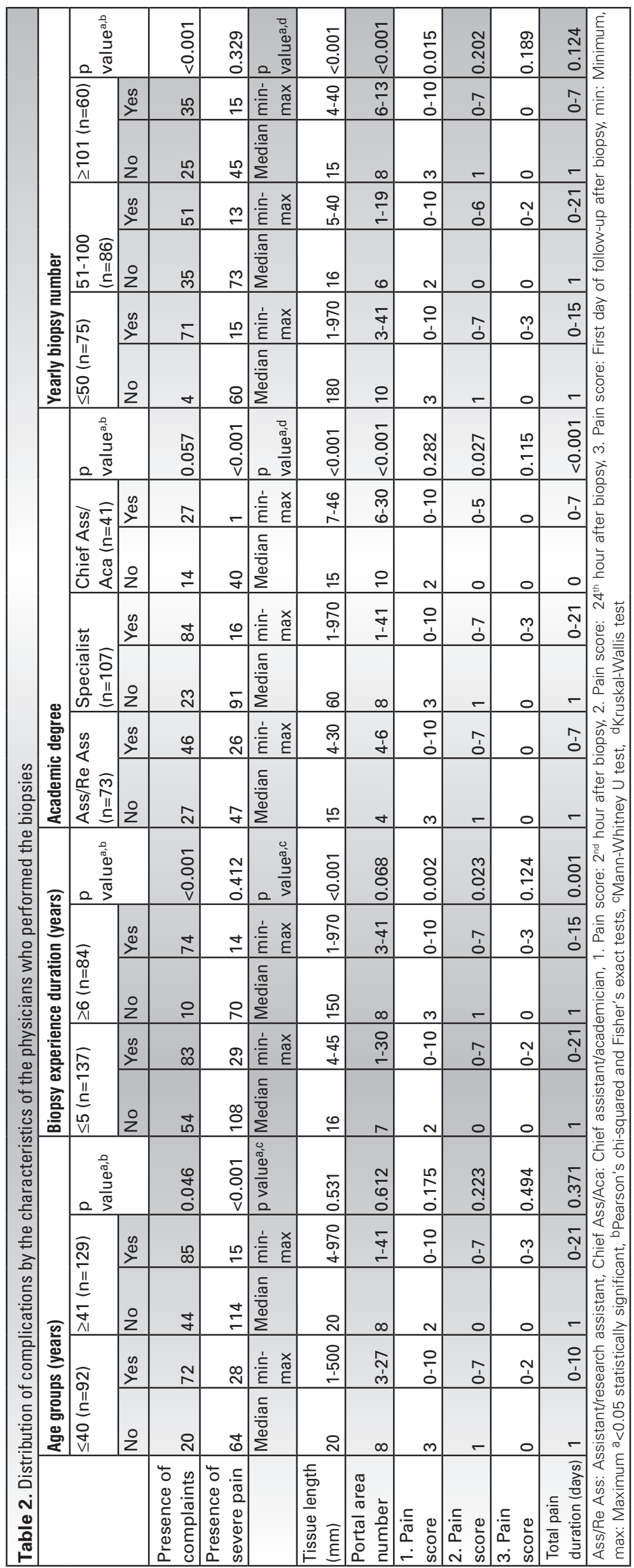

Eisenberg et al. (12) found a correlation between anxiety before a biopsy and the pain felt within the first 6 hours following the biopsy. In addition, Akay et al. (13) reported that the pain expectations of patients were high before a liver biopsy, but they felt less pain than expected during the procedure. Therefore, the presence and/or severity of pain felt after biopsy that we found in our study might be associated with the anxiety levels of the patients.

In our study, the method used did not affect the occurrence of severe pain. However, in a previous study conducted on HCV patients, the pain and related morbidity following a blind biopsy were found to be more common than in USG-guided biopsy (14). Nevertheless, there are studies showing that whether or not biopsies are performed with USG guidance makes no difference in terms of development of complications (15).

When the factors related to pain were examined, severe pain was observed more commonly after biopsies performed by young physicians and assistants/research assistants. This result could be explained by the fact that the majority of the assistants/research assistants were under 40 years of age.

In our study group, a physician's level of experience and the number of biopsy per year did not affect the development of pain. In one previous study evaluating the complications that developed following blind biopsies, it was found that less physician experience was significantly correlated with a higher rate of procedure failure, but the level of experience did not influence the development of complications (9). Chevallier al. (16) reported that the level of experience made no difference in terms of pain severity following USG-guided liver biopsies.

Similar studies have shown that the factors affecting complications were severe fibrosis (9), performing three or more interventions, female gender, the presence of malignancy, and an INR of $\geq 1.4$ (8). In our patient group, no correlation was found between pain and the level of fibrosis, gender, or the presence of chronic disease. Since our study did not include patients with coagulation disorders, INR levels were not evaluated.

Although no significant correlation was found between the biopsy methods and occurrence of severe pain, the average pain felt was higher and the mean duration of pain was longer with blind biopsies at the $2^{\text {nd }}$ and $24^{\text {th }}$ post-biopsy hours. It is believed that this result might be associated with the negative pressure created by the Menghini biopsy needles. Any patient undergoing a blind biopsy should be more closely followed-up in terms of pain severity.

No bleeding was observed in the study group. A large portion of the major complications are expected to develop within the first few hours after a biopsy (4). However, $70 \%$ of bleedings have been reported to develop after 24 hours (10), and last endup to 15 days (4). We believe that no bleeding complications were missed, since we followed up the patients for an average of 21 days after biopsy.

Factors that affect bleeding include a decreased platelet count and increased PT, INR, or APTT $(5,17)$. Terjung et al. (10) reported the factors increasing the risk of bleeding as the following: mycobacterial infection [Odds ratio (OR): 24.0], prebiopsy prophylactic platelet substitution (OR: 9.9), acute liver failure (OR: 9.1), heparin administration on the day of the biopsy (OR: 8.7), advanced liver cirrhosis (OR: 5.1), therapy with corticosteroids (OR: 3.5) or metamizole (OR: 2.8), and leukemia or lymphoma (OR: 2.8). 
Since the patients in our study did not have these specified risk factors, no bleeding was observed after biopsies.

In this study, significant correlations were determined between liver tissue length and biopsy method, and between the number of portal sites and diameter of the needle used. However, the biopsy method and diameter of the needle used did not create a significant difference in terms of obtaining sufficient material for the pathological evaluation. Therefore, we believe that it may be misleading to evaluate the efficacy of the biopsy needle by the tissue length and number of portal sites. However, the experience of the physician was found to be important in terms of the tissue length and number of portal sites included in the liver biopsy (16). In our study, biopsy experience was also found to be associated with the tissue length.

The present research contributes to the scarce number of studies that have been prospectively designed. Retrospective studies remain weak in accurately reporting the presence and severity of a subjective complication, such as pain. We believe that the data obtained from our study could be passed on to the patients to inform them on the possibility of complications that could occur after a biopsy, as well as the severity, duration, and location of the pain before the biopsy.

\section{Study Limitation}

Unlike retrospective studies, it is difficult to reach a large number of patients in prospective studies. As such, the most important limitation of our study was the smaller number of patients than in previous retrospective studies. One reason for this was that we encountered patients who did not want to share their data. Moreover, the duration of the study could not be prolonged to increase the number of patients; we did not want to encounter any additional problems, such as a change of workplace of the physicians in the clinics.

\section{Conclusion}

Based on the results of this study, we assume that both blind and USG-guided biopsies are safe and effective biopsy methods. Regardless of the method used, various degrees of pain may be felt after a biopsy; therefore, the patient should be informed about the probability of pain despite sedation before the biopsy in order to reduce the level of pain. Moreover, liver biopsies performed by experienced physicians or under their supervision may reduce post-biopsy complaints. This research showed that severe pain is not correlated by the biopsy method or patient-specific factors; however, it is related with the biopsy needle used and physicianspecific factors. Overall, these results should be supported by future studies with a larger and more diverse patient population.

\section{Ethics}

Ethics Committee Approval: The Ethics Committee of Istanbul Medeniyet University, Göztepe Training and Research Hospital approved the present study (01.07.2015-2015/0090).

Informed Consent: Written informed consent received.

Peer-review: Externally peer-reviewed.

\section{Authorship Contributions}

Surgical and Medical Practices: Z.K., F.Y.K., G.D., H.C., E.P., A.A., S.T., Y.D., S.E., Z.A., Concept: Z.K., Design: Z.K., F.Y.K., Data Collection and Processing: G.D., H.C., E.P., A.A., S.T., Y.D., S.E., Z.A.,Analysis or Interpretation: Z.K.,Literature Search: Z.K., F.Y.K., Writing: Z.K., F.Y.K.
Conflict of Interest: No conflict of interest was declared by the authors.

Financial Disclosure: The authors declared that this study received no financial support.

\section{References}

1. Piekarska A. Principles of the Biopsy Procedure. In: Takahashi H (ed). Liver Biopsy In Tech; Available from: http://www.intechopen.com/ books/liver-biopsy/principles-of-the- biopsy-procedure. 2011; p. 25-32.

2. Grant A, Neuberger J. Guidelines on the use of liver biopsy in clinical practice. Gut. 1999;45(Suppl 4):iv1-iv11. Available from: http://gut.bmj. com/cgi/doi/10.1136/gut.45.2008.iv1

3. Al-Ghamdi ASG. Complications of liver biopsy. In: Takahashi H, (ed) Liver Biopsy. InTech Published; 2011. p. 363-370. Available from: http://www.intechopen.com/books/liver- biopsy/complications-of-liverbiopsy\%0A

4. Machado NO. Complications of Liver Biopsy - Risk Factors Management and Recommendations. In: Takahashi H(ed). Liver Biopsy. InTech Published: 2011. p. 393-404. Available from: http://www. intechopen.com/books/liver-biopsy/complications-of-liver-biopsy-riskfactors-management- and-recommendations

5. Thampanitchawong P, Piratvisuth T. Liver biopsy: complications and risk factors. World J Gastroenterol. 1999;5:301-304.

6. Eti Aslan F. Ağrı Değerlendirme Yöntemleri. C Ü Hemşirelik Yüksekokulu Derg. 2002;6:9-16.

7. Weigand K, Weigand K. Percutaneous liver biopsy: Percutaneous liver biopsy: retrospective study over 15 years comparing 287 inpatients with 428 outpatients. J Gastroenterol Hepatol. 2009;24:792-799.

8. Chi $H$, Hansen BE, Tang WY, Schouten JN, Sprengers D, Taimr $P_{\text {, }}$ Janssen HL, de Knegt RJ. Multiple biopsy passes and the risk of complications of percutaneous liver biopsy. Eur J Gastroenterol Hepatol. 2017;29:36-41.

9. Szymczak A, Simon K, Inglot M, Gladysz A. Safety and effectiveness of blind percutaneous liver biopsy: Analysis of 1412 procedures. Hepat Mon. 2012;12:32-37

10. Terjung B, Lemnitzer I, Dumoulin FL, Effenberger W, Brackmann HH, Sauerbruch T, Spengler U. Bleeding complications after percutaneous liver biopsy: An analysis of risk factors. Digestion. 2003;67:138-145.

11. Myers RP, Fong A, Shaheen AA. Utilization rates, complications and costs of percutaneous liver biopsy: A population-based study including 4275 biopsies. Liver Int. 2008;28:705-712.

12. Eisenberg E, Konopniki M, Veitsman E, Kramskay R, Gaitini D, Baruch Y. Prevalence and characteristics of pain induced by percutaneous liver biopsy. Anesth Analg. 2003;96:1392-1396.

13. Akay S, Karasu Z, Noyan A, Pala S, Musoğlu A, Ilter T, Batur Y. Liver biopsy: Is the pain for real or is it only the fear of it? Dig Dis Sci. 2007:52:579-581

14. Farrell RJ, Smiddy PF, Pilkington RM, Tobin AA, Mooney EE, Temperley IJ, McDonald GS, Bowmer HA, Wilson GF, Kelleher D. Guided versus blind liver biopsy for chronic hepatitis C: clinical benefits and costs. J Hepatol. 1999;30:580-587.

15. Filingeri V, Francioso S, Sforza D, Santopaolo F, Oddi FM, Tisone G. A retrospective analysis of 1.011 percutaneous liver biopsies performed in patients with liver transplantation or liver disease : ultrasonography can reduce complications? Eur Rev Med Pharmacol Sci. 2016;20:36093617

16. Chevallier P, Ruitort F, Denys A, Staccini P, Saint-Paul MC, Ouzan D, Motamedi JP, Tran A, Schnyder P, Bruneton JN. Influence of operator experience on performance of ultrasound-guided percutaneous liver biopsy. Eur Radiol. 2004;14:2086-2091.

17. Atwell TD, Smith RL, Hesley GK, Callstrom MR, Schleck CD, Harmsen WS, Charboneau JW, Welch TJ. Incidence of bleeding after 15,181 percutaneous biopsies and the role of aspirin. AJR Am J Roentgenol. 2010:194:784-789 